\title{
STUDY OF PREVALENCE OF HYPERTENSION IN RURAL POPULATION OF KERALA
}

Dr. Pawar Anant, Dr. Shinde Pradip, Dr. Annie John.

1. Associate Professor, Department of Community Medicine, KMCT Medical College. Manasserry. P.O. Mukkam, Kozhikode,

2. Assistant Professor, Department of Community Medicine, KMCT Medical College. Manasserry. P.O. Mukkam, Kozhikode,

3. Assistant Professor, Department of Community Medicine, KMCT Medical College. Manasserry. P.O. Mukkam, Kozhikode,

\section{CORRESPONDING ADDRESS:}

Dr. Pawar Anant T.

Associate Professor,

Department of Community Medicine,

K.M.C.T. Medical College, Manasserry, P.O. Mukkam,

Kozhikode, Kerala

Email: dr.anantp@gmail.com

Phone: 00918943037075.

ABSTRACT: BACKGROUND: Hypertension is one of the important causes of cardiovascular morbidity and mortality. With change in lifestyle and increase in life expectancy in India, hypertension is emerging as an important public health problem. AIM \& OBJECTIVES: To asses the prevalence of hypertension in rural population To correlate the prevalence with epidemiological factors. METHODS: A community based cross sectional survey was conducted in rural Kerala and 459 subjects were studied. Height weight and blood pressure of subjects were measured using standardized techniques. RESULTS: The overall prevalence of hypertension in our study was $19.82 \%$. Prevalence of hypertension increased with age but did not vary with sex. The prevalence of hypertension was strongly associated with body mass index (BMI). CONCLUSIONS: This rural study showed a high prevalence of hypertension. This observation emphasises need to improve screening, treatment and control of hypertension in this population.

KEYWORDS: Cardiovascular Morbidity, urbanization, industrialization

INTRODUCTION: India is facing a dual burden of communicable and non-communicable diseases. As per WHO report hypertension ranks fourth among highly prevalent diseases in the world ${ }^{1}$. Hypertension is the one of major risk factor for cardiovascular mortality, which accounts for 20-50 percent of all deaths' ${ }^{2}$.

Because of changes in lifestyle and environment, industrialization and urbanization the prevalence of hypertension is increasing. At the same time as a result of increased life expectancy hypertension is emerging as a major health problem.

As socio-demographic differences between urban and rural population are diminished, hypertension has penetrated rural population. A community based survey was conducted in field practice area of KMCT Medical College to find out prevalence of hypertension and to study some socio-demographic factors affecting hypertension. 
AIM \& OBJECTIVES: To Asses the prevalence of hypertension in rural population. To correlate the prevalence with epidemiological factors.

MATERIALS AND METHODS: A community based cross-sectional survey was conducted in the villages of Mukkam Panchayat. This study was a part of ongoing family health survey conducted in field practice area of KMCT Medical College, Manasserry, P. O. Mukkam. A house to house survey was carried out and all members aged above 20 years were included in present study. Detailed information regarding age, sex, educational status, marital status, occupation, religion, etc. was obtained using predesigned questionnaire.

Height and weight of individual was measured using standard techniques. Blood pressure was measured by mercury sphygmomanometer, pulse obliteration and auscultation method in sitting position. Two separate reading at an interval of minimum 10 minutes were taken and average was calculated. The hypertension was defined as systolic BP equal to or more than $140 \mathrm{~mm}$ of $\mathrm{Hg}$ or diastolic BP equal to or more than $90 \mathrm{~mm}$ of $\mathrm{Hg}$ or those individuals currently taking antihypertensive treatment.[3] Data was then analyzed for the results.

RESULTS: A total of 459 persons were screened for hypertension. Distribution of population according to their soci-economic class and religion is shown in table 1 . Out of 459 persons screened for hypertension, 91 had hypertension, giving the prevalence rate of $19.82 \%$. The overall prevalence of hypertension was little more in males i.e. $21.35 \%$ than in females i.e. $18.57 \%$, but prevalence of hypertension among females more than 40 years of age was higher than males in the respective age group (table-3). However this difference was not statistically significant. Increase in prevalence was observed with increase in age in both sexes. This was statistically significant.

In present study out of 459 subjects 98 (21.35\%) were overweight (BMI- 25 to 29.9), while $19(4.13 \%)$ were obese. It was observed that prevalence of hypertension increased with increase in BMI (table-4) and this increase was also statistically significant.

DISCUSSION: Hypertension is a major public health problem in India. Various studies conducted in Kerala have estimated the prevalence of hypertension ranging from $17.9 \%$ in $1993^{[4]}$ to $51.8 \%$ in $2000 .{ }^{[5]}$ However, the study results were not consistent, due to variations in the lifestyles in different parts of country and also different age composition of the study population.

The overall prevalence of hypertension in the study subject was $19.82 \%$. The prevalence of hypertension was increased with the increase in age, it was minimum i.e. $(7.27 \%)$ in age group of 20-29 years, while it was maximum (36.84\%) in age group of above 60 years. Similar findings have been reported by other authors. $[6,7]$ Though in present study prevalence of hypertension in males $21.35 \%$ was higher than prevalence in females $18.57 \%$, the difference was not significant. Contradictory but non-significant association between sex and prevalence has been also reported by other authors too. ${ }^{[6,8,9]}$

A positive association was observed between body mass index and prevalence of hypertension. Overweight and obese persons were definitely at higher risk of hypertension. The similar findings were reported by other studies. ${ }^{7,10]}$

CONCLUSIONS: The overall prevalence of hypertension in the study subjects was $19.82 \%$. The prevalence of hypertension increased with increase in age and BMI. From this study it is evident 
that hypertension is not only a concern of the urban population, but also it has penetrated in rural areas.

RECOMMENDATIONS: Hypertension is one of the important risk factors for coronary heart disease, which is one of the important leading causes of death. Mass screening programme should be started to detect persons at risk of developing hypertension.

Information, education, and communication activities (IEC) should be started to increase the awareness of people to adopt healthy life styles like regular physical exercise, restricted salt intake, avoidance of alcohol and smoking.

\section{REFERENCES:}

1. The World Health Report 1998 - WHO Geneva, 1998.

2. K. Park. Hypertension. In: K. Park, Park's textbook of Preventive and Social Medicine $20^{\text {th }}$ edn. Jabalpur: M/s Banarsidas Bhanot Publishers; 2009: 323.

3. Chobanian AV, Bakris GL, Black HR, Cushmann WC, Green LA, Izzo JL Jr, et al. Seventh report of joint national committee on prevention, detection, evaluation and treatment of high blood pressure. Hypertension 2003; 42:1206-52.

4. Kutty VR, Balakrishnan KG, Jayasree AK, Thomas J. Prevalence of coronary heart disease in the rural population of Thiruvananthapuram district, Kerala, India. Int J Cardiol. 1993; 39(1): 59-70.

5. Kalavathy MC, Thankappan KR, Sarma PS, Vasan RS. Prevalence, awareness, treatment and control of hypertension in an elderly community-based sample in Kerala, India. Natl Med J India. 2000; 13(1): 9-15.

6. Prashanth TS, Vijaykumar K. Calicut Medical Journal [online]. Available from Calicut Medical Journal 2008; 6(3):e4

7. Todkar SS, Gujarathi VV, Tapare VS. Period prevalence and sociodemographic factors of hypertension in rural Maharashtra: A cross-sectional study. Indian J Community Med 2009; 34(3):183-7.

8. Khadilkar HA, Ghattargi CH, Thite GH. Study Of Prevalence Of Hypertension And Sociodempgraphic Factors In A Rural Community Of Maharashtra. South Asian Journal of Preventive cardiology. Available from www.sajpc.org/vol8/vol8_4/studyofprevalence.htm

9. Joshi PP, kate SK, Shegokar Y. Blood Pressure Trends And Life Style Risk Factors In Rural India. JAPI, 1993; 41(9): $579-581$.

10. Malhotra P, Kumari S, Kumar R, Jain S, Sharma BK. Prevalence and Determinants of hypertension in an unindustrialized rural population of North India. J Hum Hypertens 1999; $13: 467-72$

Table -1: Distribution of population according to socio-economic status and religion.

\begin{tabular}{|l|l|l|l|l|}
\hline \multirow{2}{*}{$\begin{array}{l}\text { Socio-economic } \\
\text { class* }\end{array}$} & \multicolumn{2}{|l|}{ Religion } & \multirow{2}{*}{ Total } \\
\cline { 2 - 4 } & Hindu & Muslim & Christain & \\
\hline I & 12 & 29 & 0 & 41 \\
\hline II & 48 & 67 & 02 & 117 \\
\hline III & 98 & 77 & 08 & 183 \\
\hline IV & 57 & 29 & 04 & 90 \\
\hline V & 19 & 09 & 0 & 28 \\
\hline Total & 234 & 211 & 14 & 459 \\
\hline
\end{tabular}


*(Socioeconomic class as per B.G.Prasad classification updated for June 2011)

Table -2: Age distribution of hypertensives

\begin{tabular}{|l|l|l|l|}
\hline Age & Total no. Of persons & $\begin{array}{l}\text { No. Of persons with } \\
\text { hypertension }\end{array}$ & $\begin{array}{l}\text { Prevalence } \\
\text { hypertension in \% }\end{array}$ \\
\hline $20-29$ & 110 & 8 & 7.27 \\
\hline $30-39$ & 87 & 11 & 12.64 \\
\hline $40-49$ & 103 & 17 & 16.5 \\
\hline $50-59$ & 64 & 20 & 31.25 \\
\hline$\geq 60$ & 95 & 35 & 36.84 \\
\hline Total & 459 & 91 & 19.82 \\
\hline ?2=36.96, $\mathrm{df}=4, \mathrm{p}<0.001$ & \\
\hline
\end{tabular}

Table-3: Age and sex distribution of persons with hypertension

\begin{tabular}{|c|c|c|c|c|c|c|}
\hline Age & Males & & & Females & & \\
\hline & $\begin{array}{l}\text { Total no. } \\
\text { Of } \\
\text { subjects }\end{array}$ & $\begin{array}{l}\text { Subjects with } \\
\text { hypertension }\end{array}$ & $\begin{array}{l}\text { Prevalence } \\
\text { in } \%\end{array}$ & $\begin{array}{l}\text { Total no. } \\
\text { Of } \\
\text { subjects }\end{array}$ & $\begin{array}{l}\text { Subjects with } \\
\text { hypertension }\end{array}$ & $\begin{array}{l}\text { Prevalence } \\
\text { in } \%\end{array}$ \\
\hline $20-29$ & 39 & 3 & 7.69 & 71 & 5 & 7.04 \\
\hline $30-39$ & 38 & 7 & 18.42 & 49 & 4 & 8.16 \\
\hline $40-49$ & 49 & 8 & 16.32 & 54 & 9 & 16.67 \\
\hline $50-59$ & 31 & 9 & 29.03 & 33 & 11 & 33.34 \\
\hline$\geq 60$ & 49 & 17 & 34.69 & 46 & 18 & 39.13 \\
\hline Total & 206 & 44 & 21.35 & 253 & 47 & 18.57 \\
\hline
\end{tabular}

Table-4: Relationship between B.M.I. and hypertension

\begin{tabular}{|l|l|l|l|l|}
\hline BMI & $\begin{array}{l}\text { No. Of persons } \\
\text { in group }\end{array}$ & Hypertensives & Normotensives & $\begin{array}{l}\text { Prevalence of } \\
\text { hypertension in } \\
\%\end{array}$ \\
\hline$<18.5$ & 79 & 10 & 69 & 12.65 \\
\hline $18.5-24.9$ & 263 & 35 & 228 & 13.3 \\
\hline $25-29.9$ & 98 & 37 & 61 & 37.75 \\
\hline$>30$ & 19 & 9 & 10 & 47.36 \\
\hline Total & 459 & 91 & 368 & 19.82 \\
\hline $\operatorname{man}^{2}=38.36, \mathrm{df}=3, \mathrm{p}<0.001$ & & & \\
\hline
\end{tabular}

